\title{
SUMBER YURIDIS PANCASILA SEBAGAI DASAR NEGARA
}

\author{
WULAN RAHMADANI \\ wulanrahmadhani23122000 \\ 20220050 \\ STIE AKBP KBP PADANG
}

\section{A. PENDAhuluan}

Pancasila merupakan sumber hukum di Indonesia, Penempatan Pancasila sebagai sumber hukum di Indonesia adalah sesuai dengan Pembukaan UUD 1945 yang menempatkan Pancasila sebagai dasar ideologi negara serta sekaligus dasar filosofis bangsa dan negara, sehingga setiap materi muatan peraturan perundang-undangan tidak boleh bertentangan dengan nilai-nilai yang terkandung dalam Pancasila.

Berbagai kebijakan hukum juga belum mampu mengimplementasikan nilai-nilai dari Pancasila yang menumbuhkan rasa kepercayaan yang tinggi terhadap hukum sebagai pencerminan adanya kesetaraan dan pelindungan hukum terhadap berbagai perbedaan pandangan, suku, agama, keyakinan, ras dan budaya yang disertai kualitas kejujuran yang tinggi, saling menghargai, saling menghormati, non diskriminatif dan persamaan di hadapan hukum. Tanpa Pancasila, masyarakat nasional kita tidak akan pernah mencapai kekukuhan seperti yang kita miliki sekarang ini.

Tampaknya, Pancasila khususnya Pancasila sebagai sumber hukum di Indonesia masih kurang dipahami benar oleh sebagian bangsa Indonesia. Padahal, maraknya korupsi, suap, main hakim sendiri, anarkis, sering terjadinya konflik dan perpecahan, dan adanya kesenjangan sosial saat ini, kalau diruntut lebih disebabkan belum dipahaminya, dihayati, dan diamalkannya Pancasila.

\section{B. PEMBAHASAN}

Pancasila dalam kedudukannya ini sering disebut sebagai Dasar Filsafat atau Dasar Falsafah Negara (Philosofische Gronslag) dari Negara, ideologi Negara atau (Staatsidee). Dalam pengertian ini pancasila merupakan suatu dasar nilai serta norma untuk mengatur pemerintahan Negara atau dengan kata lain perkataan. Pancasila merupakan suatu dasar untuk mengatur penyelenggaraan Negara. Konsekuensinya seluruh pelaksanaan dan penyelenggaraan Negara terutama segala peraturan perundang-undangan termasuk proses 
reformasi dalam segala bidang dewasa ini dijabarkan dan diderivasikan dari nilai-nilai pancasila. Maka pancasila merupakan sumber hukum di Indonesia, pancasila merupakan sumber kaidah hukum Negara yang secara konstitusional mengatur Negara Republik Indonesia beserta seluruh unsur-unsurnya yaitu rakyat wilayah, beserta pemerintah Negara Sebagai dasar Negara, Pancasila merupakan suatu asas kerokhanian yang meliputi suasana kebatinan atau cita-cita hukum, sehingga merupakan suatu sumber nilai, norma serta kaidah, baik moral maupun hukum Negara, dan menguasai hukum dasar baik yang tertulis atau Undang-Undang Dasar maupun yang tidak tertulis atau Dalam kedudukannya sebagai dasar Negara, Pancasila mempunyai kekuatan mengikat secara hukum.

Sebagai sumber dari segala hukum atau sebagai sumber tertib hukum Indonesia maka Setiap produk hukum harus bersumber dan tidak boleh bertentangan dengan Pancasila. Pancasila tercantum dalam ketentuan tertinggi yaitu Pembukaan UUD 1945, kemudian dijelmakan atau dijabarkan lebih lanjut dalam pokok-pokok pikiran, yang meliputi suasana kebatinan dari UUD 1945, yang pada akhirnya dikongkritisasikan atau dijabarkan dari UUD 1945, serta hukum positif lainnya.

Pancasila sebagai dasar filsafat negara, pandangan hidup bangsa serta idiologi bangsa dan negara, bukanlah hanya untuk sebuah rangkaian kata- kata yang indah namun semua itu harus kita wujudkan dan di aktualisasikan di dalam berbagai bidang dalam kehidupan bermasarakat, berbangsa dan bernegara.

Pancasila sebagai sumber hukum di Indonesia yang bermula dari Pancasila dasar negara dari sisi yuridisnya. Pranarka (1985) menyatakan bahwa dengan diangkatnya Pancasila sebagai dasar negara menjadikan Pancasila sebagai sumber. Secara leksikal, istilah sumber berarti tempat keluar, asal (yang berarti sumber dari segala sesuatu yang berupa tulisan, naskah, dokumen dll), jadi sumber hukum adalah tempat asal atau tempat keluar pengambilan hukum. Menurut Lazim Hamidi (2006), sumber hukum dibedakan menjadi 2 yaitu sumber hukum material dan sumber hukum formal. Sumber hukum material adalah suatu keyakinan/perasaan hukum individu dan pendapat umum yang menetukan isi hukum. Dengan demikian keyakinan/perasaan hukum individu (selaku anggota masyarakat) dan juga pendapat umum yang merupakan faktor-faktor yang dapat mempengaruhi pembentukan hukum. Sedangkan sumber hukum formal adalah bentuk atau kenyataan dimana kita dapat menemukan hukum yang berlaku. Jadi karena bentuknya itulah yang menyebabkan hukum berlaku umum, diketahui dan ditaati. Adapun yang termasuk sumber hukum formal adalah :

1. Undang-Undang 
2. Kebiasaan atau hukum tak tertulis

3. Yuresprudensi

4. Traktat

5. doktrin.

setiap hukum di Indonesia yang lahir di Indonesia harus berdasarkan pada Pancasila dengan memuat konsistensi isi mulai dari panjang atas sampai yang paling rendah hirarkinya.

Dengan mempelajari bab ini, kompetensi dasar yang diinginkan adalah peserta didik mampu:

1. Mengidentifikasi kedudukan Pnacasila dalam sistem hukum di Indonesia.

2. Menganalisis hubungan antara Pancasila dan konstitusi negara Indonesia, dan

3. Menerima Pncasila sebagai sumber hukum nasional.

\section{Sistem Norma Hukum}

Sistem norma yang berlaku bagi manusia sekurang-kurangnya terdiri atas 4 (empat) unsur norma, yakni norma moral, norma agama, norma etika atau norma sopan santun dan terakhir norma hukum. Norma hukum adalah sistem aturan yang diciptakan oleh lembaga kenegaraan yang ditunjuk melalui mekanisme tertentu. Artinya hukum diciptakan dan diberlakukan oleh institusi yang memang memiliki kompetensi atau kewenangan dalam membentuk dan memperlakukan hukum, yaitu badan legislatif. Dengan demikian, hukum di Indonesia dibentuk lembaga-lembaga seperti MPR, DPR, dan pemerintah sesuai dengan kapasitas dan jangkauan yang ingin dicapai oleh hukum tersebut. Contoh, UUD dan Ketetapan MPR adalah produk hukum yang diciptakan oleh MPR. Norma hukum memuat sanksi yang tegas dan akan segera dijatuhkan apabila dilanggar.

Hukum berisi norma-norma yang merupakan pedoman untuk bertingkah laku . Hans Kelsen (2008) seorang ahli filsafat hukum dari Jerman menyatakan bahawa norma hukum itu berjenjang dan bertingkat. Norma hukum pada suatu negara membentuk kesatuan tata hukum yang berpuncak pada Groundnorm. Hans Nawiasky mengembangkan lebih lanjut teori Hans Kelsen bahwa jenjang norma sebagaimana dikemukakan Hans Kelsen itu berkelompok-kelompok yang terdiri dari empat tingkat. Sedangkan Hans Kelsen tidak membedakan dalam kelompok-kelompok sehingga jenjang itu sifatnya umum an dua tingkat saja yaitu Grundnorm dan Norm.

Kelompok tingkatan norma menurut Hans Nawiasky tersebut, sebagai berikut:

1. Norma Fundamental Negara 
2. Aturan dasar/pokok negara

3. Undang-Undang

4. Aturan pelaksana atau aturan otonomi

Menurut Hans Nawiaski norma tertinggi dan merupakan kelompok pertama atau norma fundamental negara. Sebagai pokok fundamental negara Joeniarto menyebutkan sebagai norma pertama. Sedangan Hamid S Patamimi menyebutkan dengan cita hukum. Norma petama ini tidak dapat dibentuk dengan norma yang lebih tinggi lagi, tetapi ditetapkan oleh masyrakat dan menjadi tempat norma hukum di bawahnya.

Norma fundamental ini berisi norma yang menjadi dasar sebagai pembentukan konstitusi atau undang undang dasar suatu negara. Di dalam negara merupakan landasan dasar filosofi yang mengandung kaidah-kaidah dasar bagi pengaturan negara lebih lanjut. Di Indonesia norma tertinggi ini adalah Pancasila hal ini tercantum sebagaimana dalam pembukaan undang-undang dasar 1945, jadi pancasila sebagai dasar negara dapat disebut: (1). Norma dasar (2). Staatfundermentalnorm (3). Norma pertama (4). Cita hukum (5). Pokok kaedah negara fundamental.

Aturan daar di bawah norma fundamental Negara adalah aruran dasar arau pokok negara yang isinya bersifat pokok dan aturan umum dan garis besar, seperti pembagian kekuasaan negara, hubungan antara lembaga negara, serta hubungan negara dengan warga negara. Di Indonesia aturan dasar negara ini tertuang dalam batang tubuh undang-undang dasar 1945, ketetapan majelis permusyawaratan rakyat, serta hukum dasar tidak tertulis. Aturan dasar negara ini menjadi dasar bagi pembentukan undang-undang atau aturan yang lebih rendah.

Hamid S Atamimi mengatakan bahwa isi penting dari atuaran dasar adalah pokok pokok kebijaksanaan negara yang berisi aruran aturan untuk memberlakukan dan memberikan kekuatan terhadap norma hukum peraturan perunangan atau menggariskan tata cara membentuk peraturan perundangan yang mengikat secara umum.

\section{Makna Konstitusi}

Konstitusi sebagi terjemahan dari constitution (inggris) berasal dari istilah constituer (Perancis) yang artinya membentuk, maksudnya pembentukan suatu negara. Di Indonesia istilah konstitusi dan Undang-Undang Dasar mempunyai pengertian yang sama. Tetapi apabila dicermati lebih dalan, istilah Undang-Undang Dasar merujuk pada oengertian Wet atau Undang-Undang yang bersifat mendasar. Konstitusi lebih dipahami 
sebagai keseluruhan peraturan yang berlaku suatu pemerintahan diselenggarakan dalam suatu negara.

Menurut Koerniatmanto Soepawiro (1978) istilah konstitusi berasal dari bahasa Latin CISME yang berarti "Bersama dengan..." dan STATUE yang berarti "Membuat sesuatu agar berdiri”. Sehingga konstitusi atau Countitution berarti menetapkan secara bersama-sama atau semua yang telah ditetapkan.

Menurut Hamid S attamimi (1991) mengatakan bahwa konstitusi atau UndangUndang Dasar merupakan pemeberi pegangan dan pemberi batas, sekaligus merupakan petunjuk bagaimana suatu negara harus dijalankan.

Oleh karena itu konstitusi sangat penting bagi suatu negara, sebab dengan konstitusi menurut Djokosutono (1982), dapat diketahui :

1. Isinya memuat dasar dari struktur dan fungsi dari negara, dan

2. Bentuk, dibuat oleh lembaga yang khusus, yaitu mempunyai wewenang hukum,

Konstitusi di Indonesia yang berlaku sekarang ini adalah Undang-Undang Dasar 1945. Dalam sejarahnya kita pernah menggunakan tiga macam konstitusi yaitu :

1. 18 Agustus 1945 sampai 27 September 1949 menggunakan UUD 1945

2. 27 Desember 1949 sampai 15 Agustus 1950 menggunakan konstitusi RIS (KRIS) 1949

3. 16 Agustus 1950 sampai 5 Juli 1959 menggunakan Undang-Undang Dasar Sementara (UUDS) 1950

4. 5 Juli 1959 sampai sekarang menggunakan kembali UUD 1945

UUD 1945 sebagai konstitusi negara Republik Indonesia sampai saat ini telah mengalami 4 kali amandemen (perubahan) yang terjadi di era reformasi. Keempat amandemen tersebut adalah :

1. Amandemen pertama terjadi pada sidang umum MPR, disyahkan 19 Oktober 1999

2. Amandemen kedua terjadi pada sidang tahunan MPR, disyahkan 18 Agustus 2000

3. Amandemen ketiga terjadi pada sidang tahunan MPR, disyahkan 10 Nopember 2001, dan

4. Amandemen keempat terjadi pada sidang tahunan MPR, disyahkan 10 Agustus 2002

Dengan ditetapkannya perubahan Undang Undang Dasar ini maka berdasarkan pada Pasal 2 Aturan Tambahan, Undang Undang Dasar Republik Indonesia adalah naskah 
yang terdiri atas Pembukaan dan pasal-pasal. Pembukaan terdiri dari 4 alenia dan pada bagian Pasal terdiri atas 20 bab, 73 pasal, 3 pasal aturan peralihan dan 2 pasal aturan tambahan.

Adanya amandemen atas UUD 1945 ini telah memperbaharui dan merubah sistem ketatanegaraan negara Indonesia yang sebelumnya berdasarkan pada naskah UUD 1945 sebelum dilakukan amandemen.

\section{Pancasila, Pembukaan UUD 1945 dan Batang Tubuh UUD 1945}

Dasar negara menjadi sumber bagi pembentukan konstitusi. Sebagaimana telah dikemukakan sebelumnya bahwa dasar negara menempati kedudukan sebagai norma tertinggi negara. Sebagai norma tertinggi maka ia menjadi sumber bagi pembentukan norma-norma hukum dibawahnya. Konstitusi adalah salah satu norma norma hukum dibawah dasar negara. Dengan demikian konstitusi bersumber dari dasar negara. Norma hukum dibawahnya isinya tidak boleh bertentangan dengan norma dasar dan isi norma tersebut bertujuan mencapai cita-cita yang terkandung dalam dasar negara.

Menurut Hamid S Attamimi (1991), sebagai norma tertinggi maka dasar negara ini mempunyai fungsi :

1. Fungsi Regulatif

Fungsi Regulatif adalah sebagai tolak ukur untuk menguji apakah norma hukum yang berlaku dibawah dasar negara tersebut bertentangan atau tidak dan bersifat adil atau tidak.

2. Fungsi Konstitutif

Fungsi Konstitutif adalah sebagai pembentuk hukum bahwa tanpa adanya dasar negara tersebut maka norma hukum dibawahnya akan kehilangan maknanya sebagai hukum.

1. Pancasila dan Pembukaan UUD 1945

Pembukaan Undang-Undang dasar 1945 yang terdiri dari 4 alenia berisi nilanilai luhur bangsa yang didalamnya terdapat Pancasila dasar negara. Rangkain alenia dalam pembukaan UUD 1945 memnggambarkan proses berbangsa dan bernegara. Proses tersebut adalah:

1) Terjadinya negara tidak sekedar dimulai dari proklamasi tetapi adanya pengakuan akan hak setiap bangsa untuk memerdekakan dirinya. 
2) Adanya perjuangan bangsa Indonesia melawan penjajahan.

3) Terjadinya negara Indonesia adalah kehendak bersama seluruh bangsa Indonesia, sebagai suatu keinginan luhur bersama.

4) Negara Indonesia perlu menyusun alat-alat kelengkapan negara yang meliputi tujuan negara, bentuk negara, sistem pemerintahan negara, UUD negara dan dasar negara.

Hubungan antara Pancasila dan Pembukaan UUD 1945 adalah secara formal maupun material. Secara formal bahwa Pancasila dasar negara terdapat dalam pembukaan UUD 1945 tepatnya pada alenia IV. Secara material bahwa Pancasila merupakan norma dasar bernegara yang nantinya menentukan pembertukan tertib hukum di Indonesia. Pancasila menjadi inti dari Pembukaan UUD 1945.

Pada awalnay sidang BPUPKI I berkehendak untuk merumuskan dasar negara. Rumus dasar negara selanjutnya banyak dikemukakan oleh para pendiri negara, termasuk Ir. Soekarno pada tanggal 1 Juni 1945 dengan nama Pancasila.

2. Pancasila dan (Batang Tubuh) UUD 1945

Hubungan antara norma fundamental negara yaitu Pancasila dengan aturan dasar negara yaitu UUD 1945 dapat dilihat pada penjelasan UUD 1945 yaitu penjelasan umum angka II sebagai berikut : "Undang Undang Dasar menciptakan pokok-pokok pikiran yang terkandung dalam pembukaan di dalam pasal-pasalnya. Pokok-pokok pikiran tersebut meliputi suasana kebatinan Undang Undang Dasar negara Republik Indonesia. Pokok-pokok pikiran ini mewujudkan cita-cita hukum (rechtsidee) yang menguasai hukum dasar negara baik hukum dasar yang tertulis (Undang Undang Dasar) maupun hukum dasar yang tidak tertulis. Undang Undang Dasar menciptakan pokok-pokok pikiran ini di dalam pasal-pasalnya". Dalam penjelasan umum UUD 1945 ditegaskan bahwa Pancasila adalah cita hukum (Rechidise) yang menguasai hukum dasar negara baik tertulis maupun tidak tertulis.

Pancasila sebagai landasan filosofil untuk pedoman dalam menemukan muatan-muatan hukum. Peranan Pancasila memimbing pemikiran para pembentuk hukum sekaligus memberikan landasan yang kuat terhadap produk hukum.

Landasan norma dasar sangat diperlukan dalam pembentukan hukum, tanpa landasan norma dasar sulit untuk dibentuk bahkan akan kehilangan kekuatan spritualnya. 
Dalam ketetapan MPR RI No. III/MPR/2000 tentang Sumber Hukum Dan Tata Urutan Peraturan Perundang undangan disebutkan bahwa Pancasila merupakan sumber hukum dasar nasional Indonesia. Sumber hukum adalah sumber yang dijadikan bahan untuk penyusunan peraturan perundang-undangan.

Adapun jenis dan hirarki peraturan perundang-undangan negara Indonesia menurut MPR adalah sebagai berikut:

1) Undang Undang Dasar 1945

2) Ketetapan Majelis Permusyawaratan Rakyat Republik Indonesia.

3) Undang-Undang

4) Peraturan pemerintah pengganti Undang-Undang (Perpu)

5) Peraturan pemerintah

6) Keputusan Presiden

7) Peraturan Daerah

Dengan demikian jelas bahwa pancasila desar negara merupakan sumber hukum dasar bagi penyusunanan perundangan negara. UUD 1945 adalah peraturan perundangan tertinggi negara Indonesia yang bersumberkan pada Pancasila.

\section{PENUTUP}

Sumber hukum yang paling mendasar dari negara Republik Indonesia adalah Pancasila. Pancasila merupakan pandangan hidup bangsa Indonesia, termasuk hukum yang berlaku di Indonesia. Dengan dasar hukum pancasila, akan tercipta jiwa yang menjunjung tinggi keadilan social dan tidak bertentangan dengan norma-norma hukum yang berlaku.

Pancasila sebagai sumber hukum di Indonesia yang bertujuan untuk mengatur perilaku masyarakat didalam hubungannya antar anggota masyarakat yang lain, sehingga di harapkan mampu menjamin sebuah kepastian hukum.

Sebagai generasi muda, kita harus mengamalkan Pancasila sebagai sumber hukum yaitu dengan cara memaknai Pancasila itu sendiri.

Semoga dengan penjabaran tadi mengenai Pancasila sebagai sumber hukum di Indonesia ini menjadi suatu langkah awal kita untuk menumbuhksn rasa cinta tanah air di dalam diri warga Indonesia, serta mendorong tumbuhnya rasa rela berkorban dan selalu ingin mengabdikan diri kepada bangsa dan Negara. 


\section{DAFTAR PUSTAKA}

Darmini Roza dan Laurensius Arliman S Peran Pemerintah Daerah Di Dalam Melindungi Hak Anak Di Indonesia, Masalah-Masalah Hukum, Volume 47, Nomor 1, 2018.

Laurensius Arliman S, Komnas HAM dan Perlindungan Anak Pelaku Tindak Pidana, Deepublish, Yogyakarta, 2015.

Laurensius Arliman S, Penguatan Perlindungan Anak Dari Tindakan Human Trafficking Di Daerah Perbatasan Indonesia, Jurnal Selat, Volume 4, Nomor 1, 2016.

Laurensius Arliman S, Problematika Dan Solusi Pemenuhan Perlindungan Hak Anak Sebagai Tersangka Tindak Pidana Di Satlantas Polresta Pariaman, Justicia Islamica, Volume 13, Nomor 2, 2016.

Laurensius Arliman S, Pelaksanaan Perlindungan Anak Yang Tereksploitasi Secara Ekonomi Oleh Pemerintah Kota Padang, Veritas et Justitia, Volume 2, Nomor 1, 2016.

Laurensius Arliman S, Kedudukan Ketetapan MPR Dalam Hierarki Peraturan PerundangUndangan Di Indonesia, Lex Jurnalica, Volume 13, Nomor 3, 2016.

Laurensius Arliman S, Komnas Perempuan Sebagai State Auxialiary Bodies Dalam Penegakan Ham Perempuan Indonesia, Justicia Islamica, Volume 14, Nomor 2, 2017.

Laurensius Arliman S, Peranan Pers Untuk Mewujudkan Perlindungan Anak Berkelanjutan Di Indonesia, Jurnal Ilmu Hukum Tambun Bungai, Volume 2, Nomor 2, 2017.

Laurensius Arliman S, Mewujudkan Penegakan Hukum Yang Baik Untuk Mewujudkan Indonesia Sebagai Negara Hukum, Jurnal Hukum Doctrinal, Volume 2, Nomor 2, 2017. 
Laurensius Arliman S, Participation Non-Governmental Organization In Protecting Child Rights In The Area Of Social Conflict, The 1st Ushuluddin and Islamic Thought International Conference (Usicon), Volume 1, 2017.

Laurensius Arliman S, Partisipasi Masyarakat Dalam Pembentukan Perundang-Undangan Untuk Mewujudkan Negara Kesejahteraan Indonesia, Jurnal Politik Pemerintahan Dharma Praja, Volume 10, Nomor 1, 2017, https://doi.org/10.33701/jppdp.v10i1.379.

Laurensius Arliman S, Peran Komisi Perlindungan Anak Indonesia Untuk Mewujudkan Perlindungan Anak, Jurnal Respublica Volume 17, Nomor 2, 2018.

Laurensius Arliman S, Menjerat Pelaku Penyuruh Pengrusakan Barang Milik Orang Lain Dengan Mempertimbangkan Asas Fungsi Sosial, Jurnal Gagasan Hukum, Volume 1, Nomor 1, 2019.

Laurensius Arliman S, Ilmu Perundang-Undangan Yang Baik Untuk Negara Indonesia, Deepublish, Yogyakarta, 2019.

Laurensius Arliman S, Isdal Veri, Gustiwarni, Elfitrayenti, Ade Sakurawati, Yasri, Pengaruh Karakteristik Individu, Perlindungan Hak Perempuan Terhadap Kualitas Pelayanan Komnas Perempuan Dengan Kompetensi Sumber Daya Manusia Sebagai Variabel Mediasi, Jurnal Menara Ekonomi: Penelitian dan Kajian Ilmiah Bidang Ekonomi, Volume 6, Nomor 2, 2020.

Laurensius Arliman S, Pendidikan Kewarganegaraan, Deepublish, Yogyakarta, 2020.

Laurensius Arliman S, Makna Keuangan Negara Dalam Pasal Pasal 23 E UndangUndang Dasar 1945, Jurnal Lex Librum, Volume 6, Nomor 2 Juni 2020, http://dx.doi.org/10.46839/1ljih.v6i2.151. 
Laurensius Arliman S, Kedudukan Lembaga Negara Independen Di Indonesia Untuk Mencapai Tujuan Negara Hukum, Kertha Semaya Journal Ilmu Hukum, Volume 8, Nomor 7, 2020.

Laurensius Arliman S, Pelaksanaan Assesment Oleh Polres Kepulauan Mentawai Sebagai Bentuk Pelaksanaan Rehabilitasi Bagi Pecandu Dan Korban Penyalahgunaan Narkotika, Jurnal Muhakkamah, Volume 5, Nomor 1, 2020.

Laurensius Arliman S, Aswandi Aswandi, Firgi Nurdiansyah, Laxmy Defilah, Nova Sari Yudistia, Ni Putu Eka, Viona Putri, Zakia Zakia, Ernita Arief, Prinsip, Mekanisme Dan Bentuk Pelayanan Informasi Kepada Publik Oleh Direktorat Jenderal Pajak, Volume 17, No Nomor, 2020.

Larensius Arliman S, Koordinasi PT. Pegadaian (Persero) Dengan Direktorat Reserse Narkoba Polda Sumbar Dalam Penimbangan Barang Bukti Penyalahgunaan Narkotika, UIR Law Review, Volume 4, Nomor 2, 2020, https://doi.org/10.25299/uirlrev.2020.vol4(1).3779.

Laurensius Arliman S, Tantangan Pendidikan Kewarganegaraan Pada Revolusi 4.0, Ensiklopedia Sosial Review, Volume 2, Nomor 3, 2020.

Muhammad Afif dan Laurensius Arliman S, Protection Of Children's Rights Of The Islamic And Constitutional Law Perspective Of The Republic Of Indonesia, Proceeding: Internasional Conference On Humanity, Law And Sharia (Ichlash), Volume 1, Nomor 2, 2020.

Otong Rosadi danLaurensius Arliman S, Urgensi Pengaturan Badan Pembinaan Idelogi Pancasila Berdasarkan Undang-Undang Sebagai State Auxiliary Bodies yang Merawat Pancasila dalam Perspektif Hak Asasi Manusia, Prosiding Konferensi Nasional Hak Asasi Manusia, Kebudayaan dan Tujuan Pembangunan Berkelanjutan Indonesia pada Masa Pandemi Covid-19: Tantangan untuk Keilmuan Hukum dan Sosial Volume 1, Universitas Pancasila, Jakarta, 2020. 
